\title{
Further delineation of the continuous human neoplastic enterochromaffin cell line, KRJ-I, and the inhibitory effects of lanreotide and rapamycin
}

\author{
Mark Kidd, Geeta N Eick, Irvin M Modlin, Roswitha Pfragner', Manish C Champaneria \\ and John Murren
}

Department of Surgery, Yale University School of Medicine, TMP202, 333 Cedar Street, New Haven, Connecticut 06520, USA

${ }^{1}$ Centre for Molecular Medicine, Institute of Pathophysiology, Medical University of Graz, Graz, Austria

(Requests for offprints should be addressed to I M Modlin; Email: imodin @optonline.net)

\begin{abstract}
Small intestinal carcinoids (SICs) are the most prevalent gastrointestinal carcinoid and characterized by local invasion metastasis and protean symptomatology. The proliferative and secretory regulation of the cell of origin, the enterochromaffin (EC) cell has not been characterized. The absence of either a pure preparation of normal EC cells or human EC carcinoid cell lines has hindered the development of therapeutic agents. We therefore further characterized the neoplastic SIC cell line, KRJ-I by assessing its secretory (serotonin (5-HT)) and proliferative responses and defining its log growth phase transcriptome. Electron microscopy demonstrated oval, lobulated nuclei and substance $P$, and 5HT-positive cytoplasmic vesicles. RT-PCR detected transcripts for chromogranin A (CHGA), VMAT1 (SLC18A1), tryptophan hydroxylase (TPH1), substance P (TAC1), guanylin (GUCA2A), and SERT (SLC6A4). By immunohistochemistry, all cells were positive for CHGA, SERT, VMAT1, and TPH1. Transcriptome analysis (Affymetrix U133 Plus chips) identified somatostatin SSTR2/3, adrenergic $\alpha 1 C$ and $\beta 1$, dopamine D2, nicotinic-type cholinergic A5, A6, B1, muscarinic acetylcholine M4, and 5-HT-2A receptors. The presence of transcripts for SSTR1, SSTR2, and SSTR3 receptors was confirmed by RT-PCR and sequencing. Isoproterenol (ISO) resulted in a dose-dependent increase in intracellular cAMP $\left(E_{50}=340 \mathrm{nM}\right)$ and $5-\mathrm{HT}\left(E_{50}=81 \mathrm{nM}\right)$ which was completely inhibited by the cAMP antagonist $2^{\prime}, 5^{\prime}$-dideoxyadenosine $(10 \mu \mathrm{M})$. Preincubation with a SSTR agonist, lanreotide, inhibited Ip-stimulated 5 -HT secretion $\left(\mathrm{IC}_{50}=420 \mathrm{nM}\right)$. Both lanreotide $(10 \mathrm{nM})$ and rapamycin $(50 \mathrm{nM})$ inhibited proliferation $(20 \pm 12$ and $35 \pm 5 \%$ respectively $)$ in serum-free medium whereas gefitinib $(1 \mathrm{nM}-10 \mu \mathrm{M})$ inhibited proliferation at micromolar concentrations. KRJ-I is a neoplastic EC cell line that can be used as an in vitro model of SICs as it will allow elucidation and clarification of the secretory and proliferative mechanism(s) of neoplastic EC cells and the molecular signatures that characterize each of these responses.
\end{abstract}

Journal of Molecular Endocrinology (2007) 38, 181-192

\section{Introduction}

Neuroendocrine or 'carcinoid' tumors of the gut are generally misperceived as a rare, indolent form of neoplasia, have not rigorously been studied, are poorly understood and usually misdiagnosed. However, the perception that these tumors are exceedingly rare has been altered by the introduction of diagnostic strategies, including endoscopy, the measurement of plasma biochemical markers such as chromogranin, and nuclear medicine techniques, including somatostatin receptor scintigraphy (SRS; Boushey \& Dackiw 2002). Thus, a review of the current Surveillance Epidemiology and End Results (SEER) database indicated that small intestinal carcinoids (SICs) are not only the most prevalent gastrointestinal (GI) carcinoid but have also increased in incidence by $740 \%$ over the last three decades (Modlin et al. 2003). Similarly, the concept that
SICs are benign and indolent is meaningless given the recognition that these lesions exhibit locally aggressive invasion, substantial lymph node and hepatic metastasis with an overall 5-year survival rate of $<60 \%$ (Modlin et al. 2003, 2005). Additionally, they often secrete bioactive agents, including connective tissue growth factor $(C C N 2 / C T G F)$, that result in both local (peritoneal adhesions and bowel obstruction) and distant (cardiac and pulmonary) fibrosis reflecting the intrinsically neoplastic and biologically malignant phenotype of this neuroendocrine neoplasia (Modlin et al. 2004, Kidd et al. 2006b).

Although the cell of origin of SIC has been identified as the enterochromaffin (EC) cell, its secretory and proliferative regulation is unknown and, as a result, the progress in the development of effective therapeutic strategies has been limited. The characterization of the receptor profile, transcriptome, and mechanistic basis

DOI: $10.1677 /$ jme.1.02037 Online version via http://www.endocrinology-journals.org 
of neoplastic EC cell function is critical to defining the molecular basis of SIC disease. The availability of such information is necessary to identify appropriate secretory and proliferative regulatory targets and facilitate clinical management of this disease. To date, three human cell lines of variable applicability, namely the BON pancreatic tumor cell line (Evers et al. 1991), the COLO320DM cell line (Quinn et al. 1979) and the GOT1 cell line (Kolby et al. 2001) have been utilized as in vitro models considered to be representative of human GI carcinoids. The BON cell line, however, is a more accurate model of a pancreatic endocrine tumor (adenocarcinoid) rather than a GI carcinoid tumor (Zikusoka et al. 2005), while the COLO320DM cell line was derived from a neuroendocrine-differentiated human colorectal cancer rather than an EC cell-derived carcinoid (Park et al. 1987). The GOT1 cell line was established from a liver metastasis (of an ileal carcinoid tumor) rather than the primary GI tumor, and is characterized by a long ( $>18$ days) doubling time (Kolby et al. 2001). In this manuscript, we further characterize the rapidly growing, long-term, primary tumor-derived, human ileal EC carcinoid cell line, KRJ-I.

KRJ-I is a continuous cell line (Pfragner et al. 1996) with a doubling time of approximately 2 days that displays classical morphological and immunocytochemical features of a carcinoid (Pfragner et al. 1996). It was established in 1992 from a multifocal ileal carcinoid tumor with an insular histological appearance (type I) from a 75-year-old Caucasian male. To define whether KRJ-I could be utilized as an appropriate model system for the investigation of small intestinal EC carcinoids, our aims were to: (1) confirm the neuroendocrine, EC cell lineage of KRJ-I cells; (2) delineate their morphology; (3) define the KRJ-I transcriptome; (4) identify receptors potentially involved in secretory and proliferative regulation; (5) characterize serotonin secretion; and (6) investigate whether compounds with anti-proliferative effects in other neuroendocrine tumors, namely lanreotide (Imam et al. 1997), rapamycin (von Wichert et al. 2000), and gefitinib (Hopfner et al. 2003), inhibited KRJ-I proliferation.

\section{Materials and methods}

\section{Cell culture}

KRJ-I cells grow as a suspension culture and were cultured in Ham's F12 medium (Gibco) supplemented with $10 \%$ fetal calf serum (Sigma-Aldrich) and antibiotics (100 U penicillin $/ \mathrm{ml}+100 \mu \mathrm{g}$ streptomycin $/ \mathrm{ml}$, Sigma-Aldrich). Cells were incubated at $37^{\circ} \mathrm{C}$ with $5 \%$ $\mathrm{CO}_{2}$. Cell counts were undertaken using a Coulter ZM particle counter. The population doubling level (PDL) was calculated using the formula: $n=3 \cdot 32\left(\log X_{2}-\right.$ $\log X_{1}$ ), where $X_{2}$ is the cell count at the end of a given subculture and $X_{1}$ is the cell count of the original subculture inoculum (Hayflick 1973). PDL 20-25 was used for experiments.

\section{Confirmation of neuroendocrine, enterochromaffin cell origin of KRJ-I}

RT-PCR, immunocytochemical, and electron microscopy studies were undertaken for confirmation and characterization using established neuroendocrine and EC cell markers.

\section{Real-time RT-PCR}

RNA was extracted from $5 \times 10^{6} \mathrm{KRJ}-\mathrm{I}$ cells in log phase growth $(n=3)$ using TRIZOL (Invitrogen), and then cleaned using the Qiagen RNeasy kit in conjunction with the DNeasy Tissue kit (Qiagen Inc.) to ensure the absence of any contaminating genomic DNA. The clean RNA was then converted to cDNA using the HighCapacity cDNA Archive Kit (Applied Biosystems).

RT-PCR was performed as described by Kidd et al. (2005) using the set of SSTR-specific primers designed by Jung et al. (2006). Transcripts for ADRB1, CHGA, SLC18A1 (VMAT1), TPH1, TAC1 (substance P), GUCA2A, CHRM4, and SLC6A4 (serotonin transporter) were amplified using primers and PCR conditions detailed in Table 1. Purified PCR products were sequenced and analyzed by the W M Keck Biotechnology Resource Laboratory at Yale University using Applied Biosystems Dye terminator chemistry and an automated Applied Biosystems 373A Stretch DNA sequencer (Perkin-Elmer, Norwalk, CT, USA).

\section{Immunohistochemistry}

KRJ-I cells $\left(5 \times 10^{4}\right.$ cells/antibody $)$ were fixed in methanol and pipetted onto frosted microscope slides stained with a series of antibodies: (neuroendocrine specific: CHGA antibody (1:1000, DakoCytomation), or VMAT1 (1:100; Chemicon, Temecula, CA, USA); EC cell-specific: TPH $(1 \mu \mathrm{g} / \mathrm{ml}$, Calbiochem, San Diego, CA, USA), serotonin (DAKO, 1:20), or substance P (1:200, GeneTex, San Antonio, TX, USA) and $4^{\prime}, 6^{\prime}-$ diamidino-2-phenylindole (DAPI) $(20 \mathrm{mg} / \mathrm{ml})$ overnight at $4{ }^{\circ} \mathrm{C}$. After washing $(0 \cdot 1 \%$ Tween/phosphate buffered saline (PBS), cells were stained with secondary antibody (fluorescein isothiocyanate (FITC) antimouse/rabbit, 1:100, Promega; $1 \mathrm{~h} /$ room temperature). Fluorescence microscopy (Leica, Mannheim, Germany) was used to visualize and count the number of positive cells, with $1 \times 10^{3}$ cells counted for each antibody. As a control for non-specific staining, primary antibodies were excluded in matched groups. 
Table 1 Primers sequences used for RT-PCR amplification of neuroendocrine and EC cell markers from KRJ-I

Primer sequence $\left(5^{\prime} \rightarrow 3^{\prime}\right)$

\section{Marker}

$\beta$-adrenergic receptor type I (ADRB1)

Muscarinic type 4 receptor (CHRM4)

Chromogranin A (CHGA)

VMAT1 (SLC18A1)

Tryptophan hydroxylase (TPH1)

Substance P (TAC1)

Guanylin (GUCA2A)

SERT (SLC6A4)

$F$, forward; $R$, reverse.

\section{Confocal microscopy}

For confocal microscopy, micrographs were recorded using a confocal microscopy system equipped with three Ar488, Kr568, and HeNe633 lasers (TCS-SP; Leica, Mannheim, Germany) $400 \times$ magnification.

\section{Morphological characterization}

Transmission electron microscopy (TEM) and immunogold staining were undertaken in conjunction with the Center for Cell and Molecular Imaging at Yale Medical School. For TEM, $2 \times 10^{6} \mathrm{KRJ}-\mathrm{I}$ cells, either unstimulated or treated with $10^{-7} \mathrm{M}$ lanreotide for $10 \mathrm{~min}$, were fixed in $2.5 \%$ glutaraldehyde in $0.1 \mathrm{M}$ sodium cacodylate $(\mathrm{pH}$ 7.4) for $1 \mathrm{~h}$, washed, and postfixed in $1 \%$ osmium tetroxide in the same buffer. Fixed samples were processed for Epon embedding and thin-sectioned for TEM. Samples were viewed at $80 \mathrm{kV}$ using a Tecnai 12 Biotwin electron microscope (Hillsboro, OR, USA). For immunogold labeling of KRJ-I cells, cells were fixed in $4 \%$ paraformaldehyde and thereafter embedded in gelatin. The cells were infused with $2 \cdot 3 \mathrm{M}$ sucrose overnight at $4{ }^{\circ} \mathrm{C}$ and pieces of pellet transferred to liquid nitrogen. Following the initial preparation of ultrathin cryosections, unreacted aldehyde groups were first quenched with $0 \cdot 1 \mathrm{M} \mathrm{NH}_{4} \mathrm{Cl}$ in PBS for $10 \mathrm{~min}$ at room temperature (RT), and then non-specific-binding sites blocked by the addition of $1 \%$ fish skin gelatin in PBS for $20 \mathrm{~min}$ at RT. The primary antibody (TPH: $0 \cdot 1 \mu \mathrm{g} / \mathrm{ml}$ ) diluted in PBS/1\% fish skin gelatin (FSG) was added for $30 \mathrm{~min}$ at RT and after washing four times in PBS, grids were labeled with Protein A Gold for $30 \mathrm{~min}$ at room temperature. For double labeling, sections were exposed to mouse monoclonal serotonin (1:5, DAKO) or mouse monoclonal chromogranin A (1:50, DAKO) for $2 \mathrm{~h}$ followed by polyclonal rabbit substance $\mathrm{P}$ (1:50,
GeneTex) for a further $2 \mathrm{~h}$. Specimens were washed thrice in PBS followed by 1-h incubation in a mixture of goat anti-rabbit $10 \mathrm{~nm}$ gold and goat anti-mouse $5 \mathrm{~nm}$ gold antibodies. Thorough rinsing (five PBS washes) was followed by a 3-min postfixation in $1 \%$ glutaraldehyde. The labeled replicas were floated on distilled water and picked up on copper 460 grids for electron microscopic examination. All sections were mounted using Citifluor mounting medium (Agar Scientific, Stansted, Essex, UK). The following controls were run in parallel: (1) omission of primary antibody; (2) switching of detection systems in single labeling experiments (e.g. using mouse monoclonal followed by anti-rabbit secondary); (3) reversing the order of primary antibodies in the double labeling procedure. Grids were air-dried at room temperature and examined by electron microscopy (Tecnai 12 Biotwin electron microscope) at $80 \mathrm{kV}$.

\section{KRJ-I transcriptome}

An Affymetrix GeneChip approach (Human U133 Plus 2 Array) was used to acquire the KRJ-I transcriptome as follows. RNA was extracted from two replicates of $5 \times$ $10^{6} \mathrm{KRJ}-\mathrm{I}$ cells in log phase (described previously). For each hybridization experiment $(n=2), 10 \mu \mathrm{g}$ highquality (ratio $>1.9$ ) total RNA was provided to the Keck Affymetrix facility (Santa Clara, CA, USA) to perform cRNA labeling, hybridization, and data analysis (http://keck.med.yale.edu/affymetrix). The hybridized arrays were scanned using an Affymetrix GeneChip 3000 Scanner. Arrays were scaled to an average intensity of 500 and hybridization intensity data converted into presence/absence calls for each gene using GeneChip Operating Software (Affymetrix Inc.). The signal intensity data were then statistically analyzed using S-plus 2000 software (Mathsoft) to obtain 
correlation coefficients and scatter plots for evaluation of the reproducibility and quality of the array analysis. All microarray data have been deposited in the minimum information about microarray experiment (MIAME)compliant gene expression omnibus (GEO) database (http://www.ncbi.nlm.nih.gov/geo/) GEO accession number GSM105630. The GeneChip data were examined for the presence of neuroendocrine transcripts $C H G A$ and $S L C 18 A 1$ as well as the EC cell-specific transcripts TPH1, SLC6A4, TAC1, and GUCA2A and the cell cycle marker $\mathrm{Ki}-67$.

In addition, the presence of RNA encoding somatostatin receptor (SSTR) transcripts, adrenergic, dopaminergic, cholinergic, and muscarinic receptor transcripts was assessed, since we and other researchers (Modlin et al. 1994, Sandor et al. 1996, Lindstrom et al. 1997) have demonstrated the relationship of these receptors in the proliferative and secretory regulation of the enterochromaffin-like cells (ECL), the gastric neuroendocrine equivalent of the small intestinal EC cell. The presence of transcripts for putative regulatory receptors in KRJ-I cells was confirmed using reverse transcription (RT)-PCR as described previously.

\section{Physiological characterization}

\section{Serotonin secretion}

Isoproterenol and a somatostatin analog (BIM23014C/lanreotide), previously identified as secretory regulators in a variety of neuroendocrine cell types, were used to evaluate serotonin (5-HT) secretion (Danila et al. 2001). Isoproterenol activates adenylate cyclase via $\beta$-adrenergic receptors and is a secretory agonist, whereas lanreotide is a somatostatin analog with high affinity $\left(\mathrm{IC}_{50}<1 \mathrm{nM}\right)$ for SSTR2 and exhibits inhibitory activity. Isoproterenol was dissolved in water, and BIM-23014C was dissolved in $0.01 \mathrm{M}$ acetic acid containing $0.1 \%$ BSA (buffer A). Treatment of the cultures with solvent alone was used as the baseline control. Twenty-four hours prior to the addition of the individual compounds, cells were transferred to serum-free medium and seeded in 96-well plates at a density of $5 \times 10^{4}$ cells/well. To identify the optimal time frame for the dose-response experiments, cells were initially stimulated over $60 \mathrm{~min}$ with $10 \mu \mathrm{M}$ isoproterenol (Tran et al. 2004). Media were then collected from three wells for each time-point $(1,3,10$, $15,20,30,45$, and $60 \mathrm{~min}$ ) and serotonin measured using a commercially available serotonin EIA (Labor Diagnostika Nord, Gmbh \& Co., Nordhom, Germany) according to manufacturer's instructions for serum samples. Serumfree growth medium was used as a control. Experiments were repeated in duplicate. Once the optimal time course for 5-HT stimulation had been determined for isoproterenol, dose-response curves were generated by stimulating KRJ-I cells $\left(5 \times 10^{4}\right.$ cells/well, each concentration in triplicate) with a range of isoproterenol concentrations $\left(10^{-4}-10^{-9} \mathrm{M}\right)$. The $\mathrm{EC}_{50}$ of isoproterenol for serotonin secretion was calculated from nonlinear regression analysis using Prism 4 (Graphpad Software). In order to establish whether serotonin release was due to cell lysis: (1) cell viability was evaluated by Trypan Blue exclusion after the addition of isoproterenol or BIM-23014C and compared with the count taken prior to addition of the analogue; and (2) lactate dehydrogenase (LDH) release was measured using a commercially available LDH assay (Promega) according to the manufacturer's instructions for cultured cells to provide an indication of membrane integrity. The effect of a 10-min preincubation of KRJ-I cells with a range of BIM-23014C concentrations $\left(10^{-6}-12^{-12} \mathrm{M}\right)$ prior to evaluating the effect of isoproterenol $\left(\mathrm{EC}_{50}\right)$ on serotonin secretion was also studied.

\section{$\beta$-adrenergic receptor activation}

To test whether KRJ-I cells were physiologically responsive to the selective $\beta$-adrenergic receptor agonist isoproterenol, intracellular cAMP generation in response to isoproterenol was assayed using a cAMP ELISA assay (R\&D Research). Cells $\left(5 \times 10^{4}\right.$ cells/well, in triplicate) were stimulated with isoproterenol $\left(10^{-4}-10^{-8} \mathrm{M}\right)$ after which $0 \cdot 1 \mathrm{M} \mathrm{HCl}$ was added to each well to lyse the cells and the content then transferred to $1.5 \mathrm{ml}$ Eppendorf tubes and centrifuged at $600 \mathrm{~g}$ for $10 \mathrm{~min}$. The supernatant was transferred to clean $1.5 \mathrm{ml}$ tubes and dried using a Savant SpeedVac. Pellets were resuspended in $200 \mu \mathrm{l}$ Assay buffer ED2. All samples and controls were acetylated prior to performing the ELISA (R\&D cAMP ELISA handbook). Absorbance readings were measured at $405 \mathrm{~nm}$ on a microplate reader (Bio-Rad 3500).

To evaluate whether serotonin secretion is specifically mediated by cAMP in neoplastic EC cells, KRJ-I cells, $5 \times 10^{4}$ cells/well (in triplicate) were incubated for 30 min with the cell-permeable adenylyl cyclase inhibitor $2^{\prime}, 5^{\prime}$-dideoxyadenosine $\left(2^{\prime}, 5^{\prime}\right.$,-dd-Ado, $10^{-5} \mathrm{M}$; SigmaAldrich) followed by isoproterenol stimulation $\left(10^{-6} \mathrm{M}\right)$ for $45 \mathrm{~min}$. Isoproterenol-stimulated serotonin secretion in the absence of $2^{\prime}, 5^{\prime}$, -dd-Ado was assayed in parallel cells $\left(5 \times 10^{4}\right.$ cells/well in triplicate). Serotonin content was assayed as detailed previously.

\section{KRJ-I proliferation: effect of BIM-23014C (lanreotide), rapamycin, and gefitinib}

It has previously been reported that proliferation of the BON cell line can be inhibited by lanreotide, rapamycin, and gefitinib (Imam et al. 1997, von Wichert et al. 2000, Hopfner et al. 2003). To evaluate whether these compounds inhibited the growth of the KRJ-I cell line, cells were seeded in 96-well plates at $5 \times 10^{4}$ cells/well in Ham's F12 and $100 \mathrm{U}$ penicillin/ml $+100 \mu \mathrm{g}$ streptomycin $/ \mathrm{ml}$. BIM-23014C (dissolved in buffer A), 
rapamycin, and gefitinib (both dissolved in dimethylsulfoxide (DMSO)) were added at concentration ranging from $1 \mathrm{nM}$ to $1 \mu \mathrm{M} \quad(n=8$ wells for each substance; Zatelli et al. 2001). The final maximal concentration of buffer A or DMSO in experimental and control media was $0 \cdot 1 \%$. Cells were incubated for $72 \mathrm{~h}$ after the addition of each compound, after which MTT was added to a final concentration of $0.5 \mathrm{mg} / \mathrm{ml}$ per well. Following an additional 3 -h incubation period at $37^{\circ} \mathrm{C}, 5 \% \mathrm{CO}_{2}$, the reaction was stopped by adding acid-isopropanol and the formazan dye solubilized by adding an equal volume of acid-isopropanol as described previously. The optical density was read at $595 \mathrm{~nm}$ using a microplate reader (Bio-Rad 3500).

\section{Results}

\section{Confirmation of neuroendocrine, enterochromaffin origin of KRJ-I cells}

\section{$R T-P C R$ and immunohistochemistry}

Transcript for CHGA, SLC18A1 (VMAT1), TPH1, TAC1, GUCA2A (guanylin), and SLC6A4 (SERT) were identified in KRJ-I cells (Fig. 1A) and all were positive for
CgA and TPH proteins (Fig. 1B and C) as well as SERT and VMAT1, confirming their neuroendocrine, EC cell origin. Using confocal immunofluorescence microscopy, $100 \%$ of cells were both substance P- and serotonin-positive (Fig. 2).

\section{KRJ-I morphology}

KRJ-I cell ultrastructure demonstrated oval or irregular and lobulated nuclei, with most containing only one nucleolus. Well-developed Golgi and numerous mitochondria were present. Dense vacuolated granules were rarely found in the cytoplasm of unstimulated KRJ-I cells (data not shown). Of interest was the presence of numerous vesicles in cells preincubated with the somatostatin receptor agonist, lanreotide. TPH immunogold staining demonstrated association with the endoplasmic reticulum (ER) and Golgi (Fig. 3A). Double immunogold labeling showed colocalization of serotonin and substance $\mathrm{P}$ on the endoplasmic reticulum (Fig. 3B), Golgi, multivesicular bodies as well as exocytic endosomal vesicles. Substance $\mathrm{P}$ and chromogranin A were similarly colocalized (data not shown). Of interest was the abundance of substance

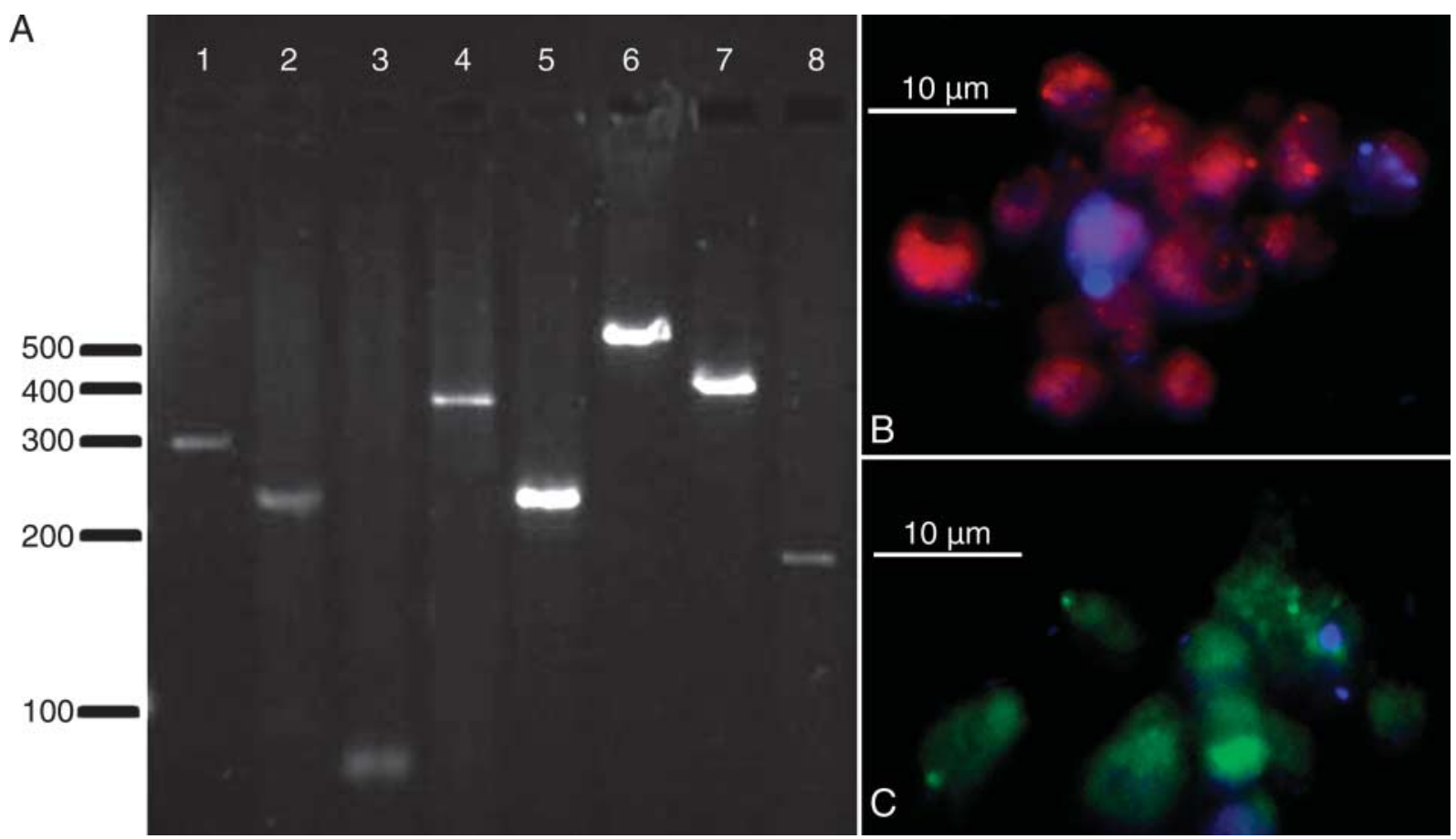

Figure 1 RT-PCR and immunohistochemical confirmation of the neuroendocrine enterochromaffin origin of KRJ-I cells. (A) RT-PCR products run on a $3 \%$ agarose gel and later excised for sequence analysis. Lane 1, SLC6A4 (SERT, 270 bp); lane 2, TAC1 (212 bp); lane 3, SLC18A1 (VMAT1, 76 bp); lane 4, ADRB1 (441 bp); lane 5, TPH1 (211 bp); lane 6, CHRM4 (430 bp); lane 7, CHGA (336 bp); lane 8, GUCA2A (guanylin, $158 \mathrm{bp}$ ). The size and the identity of these PCR products were confirmed by sequence analysis. A size bar (base pairs) is on the left. (B) KRJ-I cells (Cy-5 anti-chromogranin A, DAPI for nuclei, $400 \times$ magnification) demonstrating uniform staining for this protein. (C) KRJ-I cells (FITC anti-TPH, DAPI for nuclei $400 \times$ magnification) demonstrating uniform staining. Scale bars for each of the pictograms are included. 

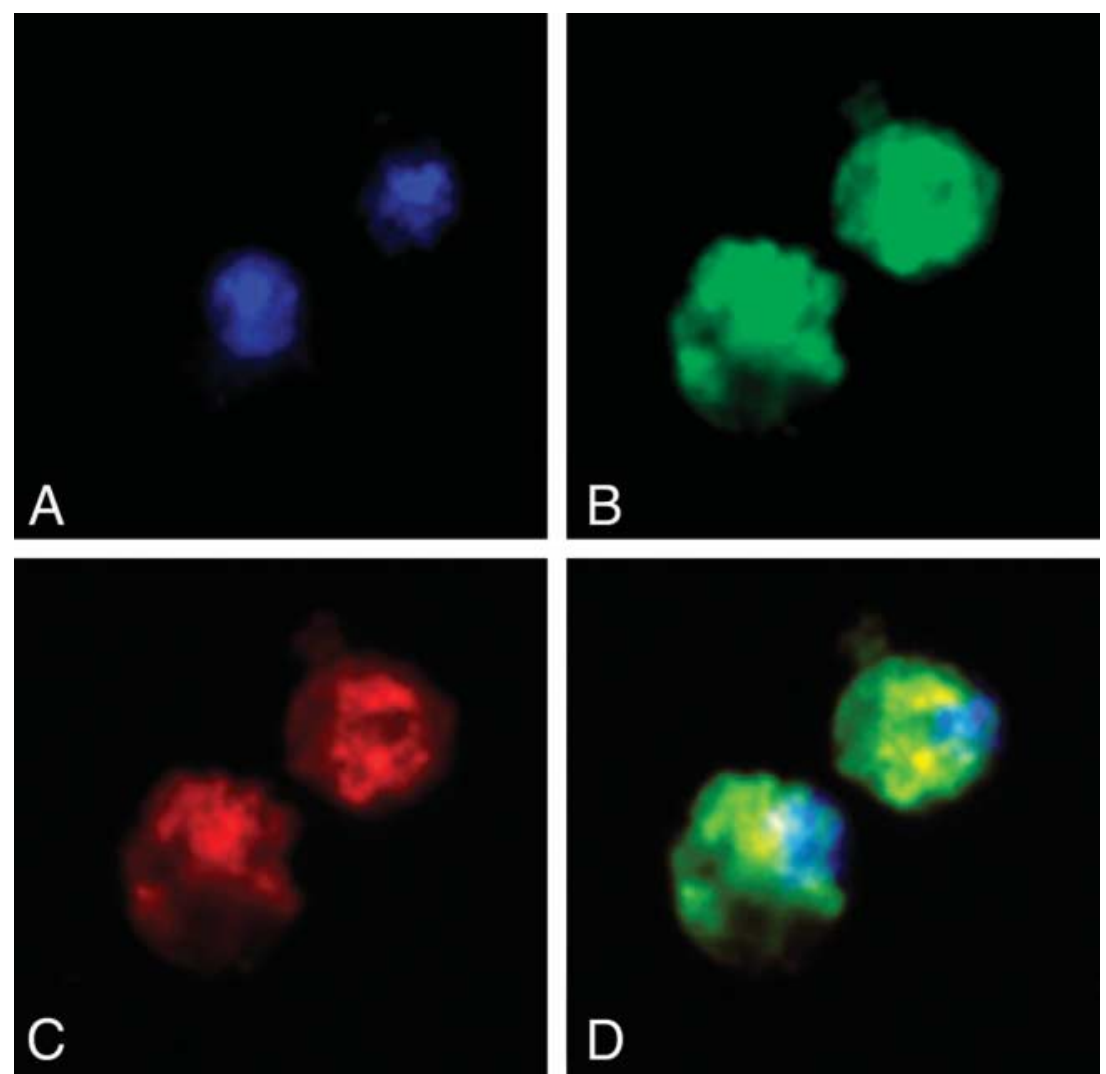

Figure 2 Confocal immunofluorescence microscopic picture of triple-stained KRJ-I cells. (A) Nuclei (blue, DAPI). (B) Substance P (green, FITC). (C) Serotonin (red, Cy5). (D) Co-localization (yellow) of substance $P$ and serotonin can clearly be identified within the cytoplasm.

$\mathrm{P}$ in the cells as well as identification of non-vesicular cytoplasmic substance $\mathrm{P}$ and serotonin in KRJ-I cells. The presence of substance P-positive exosomal bodies was also noted (Fig. 3C).

\section{Transcriptome and receptor profiling}

The two KRJ-I GeneChip hybridizations showed high correlation coefficients $\left(r^{2}=0 \cdot 97\right)$ and thus were highly reproducible. Each sample had low $3^{\prime} / 5^{\prime}$ ratios of GAPDH $<1 \cdot 0$ demonstrating consistent amplification not skewed to the $3^{\prime}$ end. Of the $>47000$ transcripts represented on the U133 Plus $2 \cdot 0$ chip, $>43.0 \%$ were scored as present in KRJ-I. Transcripts for CHGA, SLC18A1, and SLC6A4 as well as TPH1, TAC1, and GUCA2A were present, corroborating the RT-PCR and immunocytochemical results.

Candidate secretory and proliferative regulators initially identified by transcriptome analysis included SST receptor subtypes 2 and 3 (SSTR2 and SSTR3), the $\alpha 1 \mathrm{C}$ (ADRA1C) and $\beta 1(A D R B 1)$ adrenergic receptors, the dopamine D2 receptor $(D R D 2)$, the nicotinic-type cholinergic receptors A5 (CHRNA5), A6 (CHRNA6), B1 (CHRNB1), and the muscarinic acetylcholine M4 receptor (CHRM4). The serotonin 2A receptor (CHRNA5) was also present on KRJ-I based on GeneChip data.

The presence of putative regulatory receptors in KRJI cells, including SSTR2, SSTR3, the ADRB1 adrenergic receptor and the muscarinic acetylcholine M4 receptor (CHRM4) was confirmed using RT-PCR and transcripts were detected in all KRJ-I samples $(n=3)$. Additionally, RT-PCR detected the presence of transcript for SSTR1 and this result was confirmed by sequence analysis. This false-negative call on the GeneChip may be due to a combination of levels of transcript below the threshold of Affymetrix GeneChip detection and the presence of only two probes on the U133A chip with which to detect this transcript (Hill et al. 2000).

Transcript for the EGF receptor (target of gefitinib) was detected for 3/14 EGFR probes on the U133 Plus array. To confirm that transcripts for the EGFR protein were expressed, the EGFR was amplified using real-time PCR (Assays-on-Demand probe: Hs00193306_m1) and transcript was detected in all KRJ-I samples $(n=3)$. Additionally, KRJ-I cells were immunostained with anti-EGFR (5F18 - Cell Signaling Technology, Danvers, 

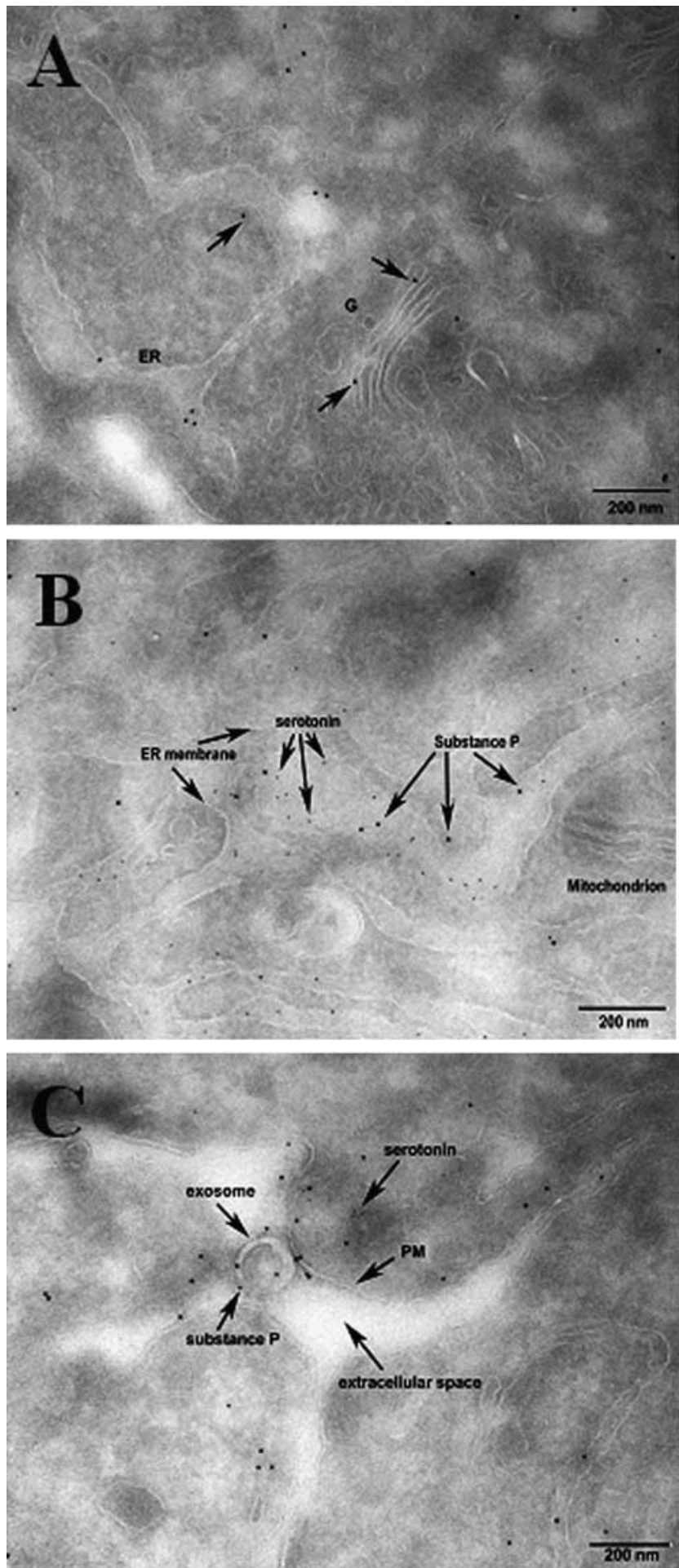

Figure 3 Electron micrographs showing (A) association of tryptophan hydroxylase with the endoplasmic reticulum (ER) and Golgi network $(G),(B)$ colocalization of substance $P(10 \mathrm{~nm}$ gold particles) and serotonin ( $5 \mathrm{~nm}$ gold particles) on the $\mathrm{ER}$, and (C) substance P-positive exosome in extracellular space. Note the absence of background labeling in the mitochondria. 

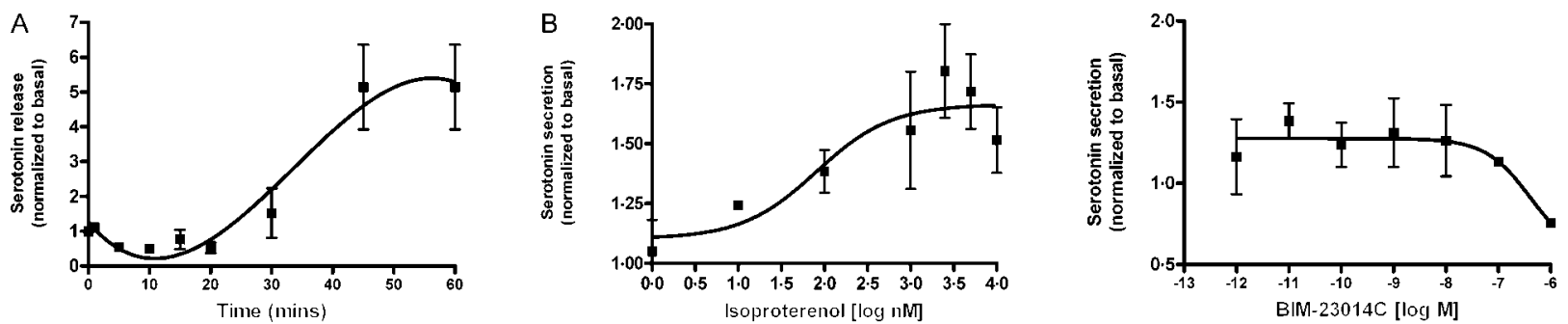

Figure 4 Isoproterenol-stimulated serotonin secretion (A) Isoproterenol-stimulated serotonin release over $1 \mathrm{~h}$. Maximal serotonin secretion occurred $45 \mathrm{~min}$ after stimulation with $10 \mu \mathrm{M}$ isoproterenol. (B) Secretion of serotonin by KRJ-I cells after stimulation with isoproterenol for $45 \mathrm{~min}$. The $\mathrm{EC}_{50}$ of isoproterenol for serotonin secretion was $81 \mathrm{nM}$. (C) Preincubation of cells with BIM$23014 \mathrm{C} /$ lanreotide inhibited serotonin secretion in response to $81 \mathrm{nM}$ isoproterenol with an $\mathrm{IC}_{50}$ of $4 \cdot 2 \times 10^{-7}$. Values are presented as the mean \pm s.D. for $n=3$ independent experiments. Some standard errors were too small $(<4 \%)$ to be graphically represented.

MA, USA). Cells were uniformly immunopositive (data not shown) confirming the presence of a gefitinibresponsive receptor.

\section{Physiological characterization}

\section{Serotonin secretion}

Isoproterenol $(10 \mu \mathrm{M})$ stimulated maximal KRJ-I serotonin secretion at $45 \mathrm{~min}$ (Fig. $4 \mathrm{~A}$ ); the dose-response study demonstrated cells with an $\mathrm{EC}_{50}$ of $81 \mathrm{nM}$ for isoproterenol (Fig. 4B). Preincubation with lanreotide inhibited isoproterenol- $\left(\mathrm{EC}_{50}\right)$ stimulated serotonin secretion with an $\mathrm{IC}_{50}$ of $0.42 \mu \mathrm{M}$ (Fig. $4 \mathrm{C}$ ).

Serotonin secretion versus serotonin release. Trypan Blue counts of cells prior to stimulation and after stimulation at different concentrations of compounds were $>95 \%$ in all cases, indicating that the serotonin measured was due to active secretion rather than passive release due to cell lysis or membrane damage. Similarly, LDH measurements supported this conclusion, with no greater than a $0 \cdot 1 \%$ maximal difference in LDH levels observed when comparing basal LDH levels with those of stimulated cells (data not shown).

Isoproterenol-induced cAMP accumulation. Isoproterenol induced a concentration-dependent increase of cAMP (Fig. 5A) with an $\mathrm{EC}_{50}$ of $340 \mathrm{nM}$.

Serotonin-secretion by KRJ-I inhibited by $2^{\prime}, 5^{\prime}$-dideoxyadenosine. Preincubation of KRJ-I cells with $10 \mu \mathrm{M}$ cAMP antagonist $2^{\prime} 5^{\prime}$-dideoxyadenosine completely inhibited isoproterenol-stimulated serotonin secretion,

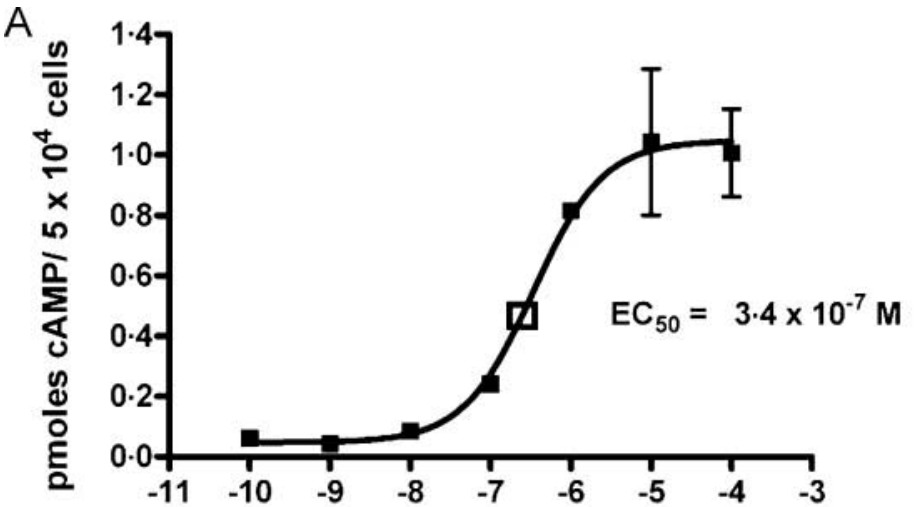

$\log$ [lsoproterenol] M

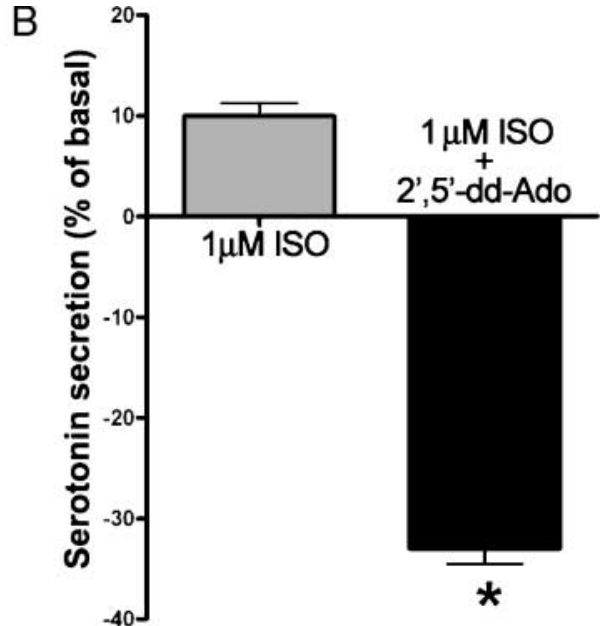

Figure $5 \beta$-Adrenergic activation stimulates cAMP production and serotonin secretion in KRJ-I cells. (A) KRJ-I cells incubated for 45 min with isoproterenol generated increasing amounts of cAMP in a concentration-dependent manner. The concentration of isoproterenol that generated a half-maximal response $\left(E_{50}\right)$ was calculated using nonlinear regression analysis. The $\mathrm{EC}_{50}$ value of isoproterenol to increase cAMP in KRJ-I cells was calculated to be $3.4 \times 10^{-7} \mathrm{M}$. Mean \pm s.E. for $n=3$ experiments. (B) The membrane-permeable cAMP inhibitor $2^{\prime}, 5^{\prime}$ dideoxyadenosine $\left(2^{\prime}, 5^{\prime}\right.$,-dd-Ado, $\left.10 \mu \mathrm{M}\right)$ completely inhibited isoproterenol (ISO, $\left.1 \mu \mathrm{M}\right)$. stimulated serotonin secretion (measured over $45 \mathrm{~min}$ ), with a reduction of serotonin levels to $73 \%$ of basal. Values are presented as the mean \pm s.D. from three independent experiments. ${ }^{\star} P<0.0001$ versus ISO. Some standard errors were too small ( $<4 \%$ ) to be graphically represented. 
with a reduction of serotonin levels to $73 \%$ of basal (Fig. 5B), indicating that serotonin secretion by KRJ-I cells is, at least in part, cAMP mediated.

\section{Inhibition of KRJ-I proliferation by lanreotide and rapamycin}

Both lanreotide and rapamycin inhibited proliferation (Fig. 6). Lanreotide at $10 \mathrm{nM}(20 \pm 12 \%$; Fig. $6 \mathrm{~A})$ and rapamycin (target of rapamycin (TOR) signaling) at

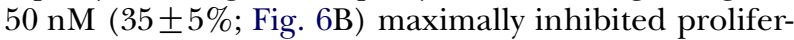
ation, whereas gefitinib (tyrosine kinase inhibitor, $1 \mathrm{nM}-10 \mu \mathrm{M})$ inhibited proliferation only at micromolar concentrations (Fig. 6C).

\section{Discussion}

KRJ-I is the only rapidly dividing, continuous human EC carcinoid cell line currently established. The paucity of other available carcinoid cell lines is the consequence of a number of factors including: (1) the limited amount of neoplastic tissue available for establishment of the cell line; (2) the generally slow proliferation times of carcinoid primary cell cultures; (3) substantial problems with bacterial and fungal infection given the bowel origin of the material; and (4) the low long-term survival rate of primary carcinoid cultures (DebonsGuillemin et al. 1982, Ahlman et al. 1989, Nilsson et al. 1992, Pfragner et al. 1996, Westberg et al. 1997).

The KRJ-I cell line was established from tissue obtained from the primary tumor of an ileal carcinoid tumor metastatic to the liver and the lymph nodes (Pfragner et al. 1996). The presence of markers of both neuroendocrine (CgA and VMAT1) and EC cells (TPH, SERT, and substance P) substantiate that KRJ-I is an appropriate model for in vitro studies of EC cell SICs.
KRJ-I also displayed morphological features characteristic of secretory cells, for example, the presence of well-developed Golgi apparatus and numerous mitochondria and the presence of substance $\mathrm{P}$ - and serotonin-containing vesicles consistent with secretory function. The identification of tryptophan hydroxylase localized to the ER and Golgi, and serotonin and substance $\mathrm{P}$ in endosomal and exosomal vesicles as well as the ER and Golgi provides further validation that this cell line is of EC origin. Transcriptome analysis revealed the presence of transcripts for a variety of known secretory and proliferative regulators of neuroendocrine cells. The presence of catecholaminergic and cholinergic pathways is consistent with current concepts of the physiology of enterochromaffin cells given that EC cells, when stimulated via $\beta$-adrenergic receptor activation - noradrenaline (Modlin et al. 2006, Kidd et al. 2006a), vagal cholinergic activation (Kuemmerle et al. 1987), or via luminal activation (pressure; Fujimiya et al. 1997) secrete 5-HT.

The basal secretion of serotonin by these neoplastic EC cells supports the clinical observation that such tumors continuously produce and release the amine into the circulation as evidenced by elevated plasma levels of serotonin and increased urinary 5-hydroxy indole acetic acid levels (Modlin et al. 2005). The low values of media serotonin noted over the first 15-30min culture potentially reflects the rapid uptake of serotonin by SERT (Gershon 2003) and is supported by studies in the GOT1 cell line that demonstrate high levels of the main serotonin metabolite, 5-HIAA, in culture media (Kolby et al. 2001). In these studies, a high turnover of serotonin was noted due to the complete intracellular metabolism with rapid release of the metabolite into the culture medium. As KRJ-I is also derived from a neuroendocrine carcinoid, and these tumors are known to demonstrate high serotonin
A

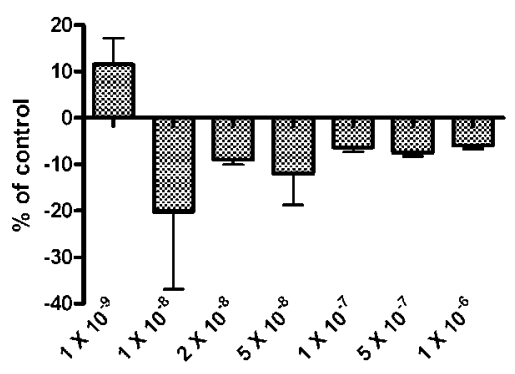

Lanreotide (M)

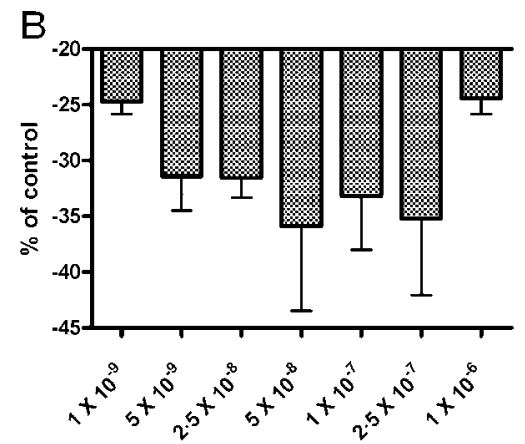

Rapamycin (M)

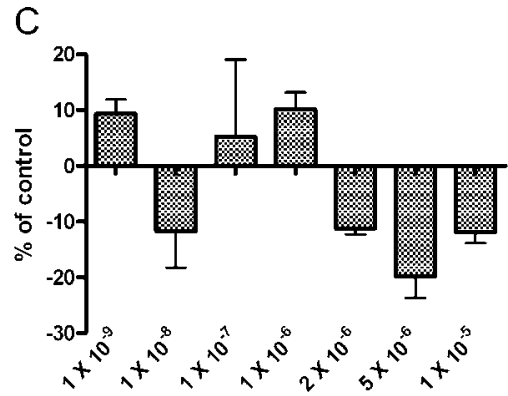

Gefitinib (M)

Figure 6 Effect of pharmacological agents on KRJ-I proliferation. (A) Proliferation was measured by MTT uptake and is represented as percentage of difference to control (unstimulated cells). Lanreotide inhibited KRJ-I proliferation with a maximal effect of $20 \pm 12 \%$ at $10 \times 10^{-9} \mathrm{M}$. (B) Rapamycin inhibited proliferation with a maximal effect of $35 \pm 15 \%$ at $5 \times 10^{-9} \mathrm{M}$. An inhibitory effect $>20 \%$ was identified at concentrations as low as $1 \times 10^{-9} \mathrm{M}$. (C) Gefitinib had no effect on KRJ-I proliferation except when used in micromolar $\left(2 \times 10^{-9} \mathrm{M}\right)$ concentrations. The maximal effect was noted at $5 \times 10^{-6} \mathrm{M}(20 \pm 8 \%$ inhibition). Values are presented as the mean \pm S.D. from three independent experiments. 
catabolism (Westberg et al. 1997), the results in Fig. 4 are biologically consistent with this cell type. Of note was the observation that isoproterenol-stimulated serotonin secretion $60 \%$ above basal levels, consistent with information derived from enteroglucagon and neurotensin cells and the presence of adrenergic receptors identified in the transcriptome (Barber et al. $1986 a$, b. Buchan et al. 1987). This major release in association with exposure to an adrenergic agent is consistent with clinical reports of sudden paroxysmal crises associated with trauma or anesthetic induction and the major release of catecholamines that occur under such conditions (Bissonnette et al. 1990, Koopmans et al. 2005). In contradistinction, the BON cell line when stimulated by isoproterenol released little serotonin ( $\sim 4 \%$ above basal) further reinforcing the fact that it is not of EC origin and does not reflect the clinical behavior of a SIC (Wallukat 2002, Tran et al. 2004).

Also, of note was the observation that isoproterenolinduced serotonin secretion was completely inhibited by the cAMP analog $2^{\prime} 5^{\prime}$-dideoxyadenosine. This would suggest that KRJ-I serotonin secretion is a cAMPmediated event and is consistent with cAMP-mediated serotonin secretion noted in rat Leydig cells and the neuroectodermal cell line MTC (Tamir et al. 1990, Tinajero et al. 1993).

As predicted, based on the presence of the SSTR2 receptor on this cell line, the SST agonist BIM-23014C inhibited the isoproterenol-stimulated secretion of serotonin by KRJ-I cells in a dose-dependent manner with an $\mathrm{IC}_{50}$ in the sub-micromolar range $(0 \cdot 42 \mu \mathrm{M})$. The cell system therefore provides evidence of having both a functional secretory mechanism and of being appropriately responsive to an agent known to activate the SSTR2 receptor and effectively decrease serotonin secretion and hence ameliorate clinical symptomatology.

The anti-proliferative effect of lanreotide on KRJ-I proliferation is of interest; although some clinical studies have proposed that somatostatin analogues inhibit tumor growth (stabilization), the evidence has largely been equivocal and there appears to be inconsistent data when comparing in vitro studies, animal experiments, and clinical experience (Schally 1988, Patel et al. 1995, Arnold et al. 1996, Rohaizak \& Farndon 2002, Modlin et al. 2005, Plockinger et al. 2005). It is likely that many of the apparent differences in tumor inhibitory data reflect the variety of models used as well as the numerous alternative regulatory pathways responsible for neoplastic cell proliferation and especially neuroendocrine neoplasia itself (Sippel \& Chen 2002, Sippel et al. 2003, Goke et al. 2004, Van Gompel \& Chen 2004, Hofsli et al. 2005, Van Gompel et al. 2005). Rapamycin targets the mTOR protein which controls cell growth and has been shown to exert anti-proliferative effects on a number of human tumor cell lines (Jacinto \& Hall 2003, Rowinsky 2004, Rao et al. 2005), including the BON cell line (von Wichert et al. 2000) and the KRJ-I cell line (this study) indicating that it may represent a novel therapeutic target for pancreatic and carcinoid tumors. Gefitinib inhibited KRJ-I proliferation at micromolar concentrations, similar to its effect in the BON cell line (Hopfner et al. 2003). The effectiveness of gefitinib only at high concentrations may indicate that the EGFR signaling pathway is not a primary growth activation pathway for KRJ-I cells. An alternative possibility is that KRJ-I cells may be characterized by a constitutively active K-Ras and/or SRC phenotype. Both these products activate the same downstream targets as the EGFR, namely Akt and Erk, and resistance to gefitinib due to activation of these products has been demonstrated in human gallbladder adenocarcinoma cell lines (Qin et al. 2006). We have sequenced codons 12 and 13 (exon 1) of the $K-R A S$ gene which represent common mutational hotspots within this gene (Kahn et al. 1987) but have detected no mutations (M Kidd, unpublished data). Although low concentrations of gefitinib appeared to stimulate KRJ-I proliferation, these results were not significantly different from the unstimulated control. Further studies are required to investigate the contribution of the EGFR signaling pathway to KRJ-I proliferation and the activation status of the downstream signaling components.

In these studies, we confirm the neuroendocrine, EC cell lineage of KRJ-I cells, define the KRJ-I transcriptome and identify receptors that may potentially be involved in secretory and proliferative regulation, characterize serotonin secretion, and demonstrate that lanreotide, rapamycin, and gefitinib, compounds with anti-proliferative effects in other neuroendocrine tumors (von Wichert et al. 2000, Hopfner et al. 2004), only have a moderate effect in this tumor cell line.

We have recently produced and characterized a $99 \%$ pure homogenous human ileal EC cell preparation (Modlin et al. 2006), and expect that the identification of upregulated receptors linked to cell proliferation in KRJ-I relative to normal EC cells will provide areas of important regulatory information that define the differences between normal and neoplastic EC cells. The opportunity to dissect out the mechanistic basis of EC cell neoplasia, as well as identify appropriate molecular targets, has obvious scientific and clinical relevance and application.

\section{Acknowledgements}

This work is supported in part by NIH R01-CA-097050 (I M M) and the Bruggeman Medical Foundation. The authors declare that there is no conflict of interest that would prejudice the impartiality of this scientific work. 


\section{References}

Ahlman H, Wigander A, Molne J, Nilsson O, Karlsson JE, Theodorsson E \& Dahlstrom A 1989 Presence of nerve growth factor-like immunoreactivity in carcinoid tumour cells and induction of a neuronal phenotype in long-term culture. International Journal of Cancer 43 949-955.

Arnold R, Trautmann ME, Creutzfeldt W, Benning R, Benning M, Neuhaus C, Jurgensen R, Stein K, Schafer H, Bruns C et al. 1996 Somatostatin analogue octreotide and inhibition of tumour growth in metastatic endocrine gastroenteropancreatic tumours. GUT 38 430-438.

Barber DL, Buchan AM, Walsh JH \& Soll AH 1986a Regulation of neurotensin release from canine enteric primary cell cultures. American Journal of Physiology 250 G385-G390.

Barber DL, Buchan AM, Walsh JH \& Soll AH $1986 b$ Isolated canine ileal mucosal cells in short-term culture: a model for study of neurotensin release. American Journal of Physiology $\mathbf{2 5 0}$ G374-G384.

Begueret H, Vergier B, Begueret J, Vernejoux JM, Jougon J, Trouette R, Taytard A, Velly JF, Merlio JP \& de Mascarel A 2002 Detection of circulating cells expressing chromogranin A gene transcripts in patients with lung neuroendocrine carcinoma. European Journal of Cancer 382325.

Bissonnette RT, Gibney RG, Berry BR \& Buckley AR 1990 Fatal carcinoid crisis after percutaneous fine-needle biopsy of hepatic metastasis: case report and literature review. Radiology 174 751-752.

Boushey RP \& Dackiw AP 2002 Carcinoid tumors. Current Treatment Options in Oncology 3 319-326.

Buchan AM, Barber DL, Gregor M \& Soll AH 1987 Morphologic and physiologic studies of canine ileal enteroglucagon-containing cells in short-term culture. Gastroenterology 93 791-800.

Buchli R, Ndoye A, Arredondo J, Webber RJ \& Grando SA 2001 Identification and characterization of muscarinic acetylcholine receptor subtypes expressed in human skin melanocytes. Molecular and Cellular Biochemistry 22857.

Chernogubova E, Hutchinson DS, Nedergaard J \& Bengtsson T 2005 $\alpha 1$ - and $\beta 1$-Adrenoceptor signaling fully compensates for $\beta 3$ adrenoceptor deficiency in brown adipocyte norepinephrinestimulated glucose uptake. Endocrinology 146 2271-2284.

Danila DC, Haidar JN, Zhang X, Katznelson L, Culler MD \& Klibanski A 2001 Somatostatin receptor-specific analogs: effects on cell proliferation and growth hormone secretion in human somatotroph tumors. Journal of Clinical Endocrinology and Metabolism 86 2976-2981.

Debons-Guillemin MC, Launay JM, Roseto A \& Peries J 1982 Serotonin and histamine production by human carcinoid cells in culture. Cancer Research 42 1513-1516.

Evers BM, Townsend CM Jr, Upp JR, Allen E, Hurlbut SC, Kim SW, Rajaraman S, Singh P, Reubi JC \& Thompson JC 1991 Establishment and characterization of a human carcinoid in nude mice and effect of various agents on tumor growth. Gastroenterology 101 303-311.

Fujimiya M, Okumiya K \& Kuwahara A 1997 Immunoelectron microscopic study of the luminal release of serotonin from rat enterochromaffin cells induced by high intraluminal pressure. Histochemistry and Cell Biology 108 105-113.

Gershon MD 2003 Plasticity in serotonin control mechanisms in the gut. Current Opinion in Pharmacology 3 600-607.

Goke R, Gregel C, Goke A, Arnold R, Schmidt H \& Lankat-Buttgereit B 2004 Programmed cell death protein 4 (PDCD4) acts as a tumor suppressor in neuroendocrine tumor cells. Annals of the New York Academy of Sciences 1014 220-221.

Gustafsson BI, Thommesen L, Stunes AK, Tommeras K, Westbroek I, Waldum HL, Slordahl K, Tamburstuen MV, Reseland JE \& Syversen U 2006 Serotonin and fluoxetine modulate bone cell function in vitro. Journal of Cellular Biochemistry 98 139-151.
Harmar AJ, Armstrong A, Pascall JC, Chapman K, Rosie R, Curtis A, Going J, Edwards CR \& Fink G 1986 cDNA sequence of human betapreprotachykinin, the common precursor to substance $\mathrm{P}$ and neurokinin A. FEBS Letters 208 67-72.

Hayflick L 1973 Subculturing human diploid fibroblast cultures. In Tissue Culture Methods and Applications, pp 220-223. Eds PF Kruse \& MK Patterson. New York: Academic Press.

Hill AA, Hunter CP, Tsung BT, Tucker-Kellogg G \& Brown EL 2000 Genomic analysis of gene expression in C. elegans. Science $\mathbf{2 9 0}$ 809-812.

Hofsli E, Thommesen L, Yadetie F, Langaas M, Kusnierczyk W, Falkmer U, Sandvik AK \& Laegreid A 2005 Identification of novel growth factor-responsive genes in neuroendocrine gastrointestinal tumour cells. British Journal of Cancer 92 1506-1516.

Hopfner M, Sutter AP, Gerst B, Zeitz M \& Scherubl H 2003 A novel approach in the treatment of neuroendocrine gastrointestinal tumours. Targeting the epidermal growth factor receptor by gefitinib (ZD1839). British Journal of Cancer 89 1766-1775.

Hopfner M, Sutter AP, Huether A, Ahnert-Hilger G \& Scherubl H 2004 A novel approach in the treatment of neuroendocrine gastrointestinal tumors: additive antiproliferative effects of interferon-gamma and meta-iodobenzylguanidine. BMC Cancer 423.

Huynh TT, Pacak K, Brouwers FM, Abu-Asab MS, Worrell RA, Walther MM, Elkahloun AG, Goldstein DS, Cleary S \& Eisenhofer G 2005 Different expression of catecholamine transporters in phaeochromocytomas from patients with von Hippel-Lindau syndrome and multiple endocrine neoplasia type 2. European Journal of Endocrinology 153 551-563.

Imam H, Eriksson B, Lukinius A, Janson ET, Lindgren PG, Wilander E \& Oberg K 1997 Induction of apoptosis in neuroendocrine tumors of the digestive system during treatment with somatostatin analogs. Acta Oncologica 36 607-614.

Jacinto E \& Hall MN 2003 Tor signalling in bugs, brain and brawn. Nature Reviews. Molecular Cell Biology 4 117-126.

Jung Y, Oh SH, Zheng D, Shupe TD, Witek RP \& Petersen BE 2006 A potential role of somatostatin and its receptor SSTR4 in the migration of hepatic oval cells. Laboratory Investigation 86 477-489.

Kahn S, Yamamoto F, Almoguera C, Winter E, Forrester K, Jordano J \& Perucho M 1987 The $c$-K-ras gene and human cancer (review). Anticancer Research 7 639-652.

Kidd M, Eick G, Shapiro MD, Camp RL, Mane SM \& Modlin IM 2005 Microsatellite instability and gene mutations in transforming growth factor-beta type II receptor are absent in small bowel carcinoid tumors. Cancer 103 229-236.

Kidd M, Modlin IM, Eick GN \& Champaneria MC $2006 a$ Isolation, functional characterization and transcriptome of mastomys ileal enterochromaffin cells. American Journal of Physiology. Gastrointestinal and Liver Physiology 291 G778-G791.

Kidd M, Modlin IM, Shapiro M, Camp RL, Mane SM, Usinger W \& Murren JR 2006b CTGF intestinal stellate cells and carcinoid fibrogenesis. World Journal of Gastroenterology In press.

Kolby L, Bernhardt P, Ahlman H, Wangberg B, Johanson V, Wigander A, Forssell-Aronsson E, Karlsson S, Ahren B, Stenman G et al. 2001 A transplantable human carcinoid as model for somatostatin receptormediated and amine transporter-mediated radionuclide uptake. American Journal of Pathology 158 745-755.

Koopmans KP, Brouwers AH, De Hooge MN, Van der Horst-Schrivers AN, Kema IP, Wolffenbuttel BH, De Vries EG \& Jager PL 2005 Carcinoid crisis after injection of 6-18F-fluorodihydroxyphenylalanine in a patient with metastatic carcinoid. Journal of Nuclear Medicine 46 1240-1243.

Kuemmerle JF, Kraus H \& Kellum JM 1987 Serotonin release is mediated by muscarinic receptors on duodenal mucosal cells. Journal of Surgical Research 43 139-142.

Lee SH, Paeng JP, Jung HH, Lee SH, Lee HM, Kwon SY, Lim KJ \& Jung KY 2004 Expression of guanylin and uroguanylin mRNA in human nasal mucosa and nasal polyps. Acta Otolaryngology 124 179-185. 
Lindstrom E, Bjorkqvist M, Boketoft A, Chen D, Zhao CM, Kimura K \& Hakanson R 1997 Neurohormonal regulation of histamine and pancreastatin secretion from isolated rat stomach ECL cells. Regular Peptides 71 73-86.

Maurer P, Rorive S, de Kerchove d'Exaerde A, Schiffmann SN, Salmon I \& de Launoit Y 2004 The Ets transcription factor Fev is specifically expressed in the human central serotonergic neurons. Neuroscience Letters 357215.

Modlin IM, Lawton GP, Tang LH, Geibel J, Abraham R \& Darr U 1994 The mastomys gastric carcinoid: aspects of enterochromaffin-like cell function. Digestion 55 (Suppl 3) 31-37.

Modlin IM, Lye KD \& Kidd M 2003 A 5-decade analysis of 13715 carcinoid tumors. Cancer 97 934-959.

Modlin IM, Shapiro MD \& Kidd M 2004 Carcinoid tumors and fibrosis: an association with no explanation. American Journal of Gastroenterology 99 2466-2478.

Modlin IM, Kidd M, Latich I, Zikusoka MN \& Shapiro MD 2005 Current status of gastrointestinal carcinoids. Gastroenterology 128 $1717-1751$.

Modlin IM, Kidd M, Pfragner R, Eick GN \& Champaneria MC 2006 The functional characterization of normal and neoplastic human enterochromaffin cells. Journal of Clinical Endocrinology and Metabolism 91 2340-2348.

Nilsson O, Wangberg B, Theodorsson E, Skottner A \& Ahlman H 1992 Presence of IGF-I in human midgut carcinoid tumours - an autocrine regulator of carcinoid tumour growth? International Journal of Cancer 51 195-203.

Park JG, Oie HK, Sugarbaker PH, Henslee JG, Chen TR, Johnson BE \& Gazdar A 1987 Characteristics of cell lines established from human colorectal carcinoma. Cancer Research 47 6710-6718.

Patel YC, Greenwood MT, Panetta R, Demchyshyn L, Niznik H \& Srikant CB 1995 The somatostatin receptor family. Life Science $\mathbf{5 7}$ 1249-1265.

Pfragner R, Wirsnsberger G, Niederle B, Behmel A, RInner I, Mandl A, Wawrina F, Luo J, Adamiker D, Hoger H et al. 1996 Establishment of a continuous cell line from a human carcinoid of the small intestine (KRJ-I): characterization and effects of 5-azacytidine on proliferation. International Journal of Oncology 8 513-520.

Plockinger U, Rindi G, Arnold R, Eriksson B, Krenning EP, de Herder WW, Goede A, Caplin M, Wiedenmann B, Oberg K et al. 2005 Guidelines for the diagnosis and treatment of neuroendocrine gastrointestinal tumours. Neuroendocrinology 80 394-424.

Qin B, Ariyama H, Baba E, Tanaka R, Kusaba H, Harada M \& Nakano S 2006 Activated Src and Ras induce gefitinib resistance by activation of signaling pathways downstream of epidermal growth factor receptor in human gallbladder adenocarcinoma cells. Cancer Chemotherapy and Pharmacology In press.

Quinn LA, Moore GE, Morgan RT \& Woods LK 1979 Cell lines from human colon carcinoma with unusual cell products, double minutes, and homogeneously staining regions. Cancer Research 39 4914-4924.

Rao RD, Mladek AC, Lamont JD, Goble JM, Erlichman C, James CD \& Sarkaria JN 2005 Disruption of parallel and converging signaling pathways contributes to the synergistic antitumor effects of simultaneous mTOR and EGFR inhibition in GBM cells. Neoplasia 7 921-929.
Rohaizak M \& Farndon JR 2002 Use of octreotide and lanreotide in the treatment of symptomatic non-resectable carcinoid tumours. ANZ Journal of Surgery 72 635-638.

Rowinsky EK 2004 Targeting the molecular target of rapamycin (mTOR). Current Opinion in Oncology 16 564-575.

Sandor A, Kidd M, Lawton GP, Miu K, Tang LH \& Modlin IM 1996 Neurohormonal modulation of rat enterochromaffin-like cell histamine secretion. Gastroenterology 110 1084-1092.

Schally AV 1988 Oncological applications of somatostatin analogues. Cancer Research 48 6977-6985.

Sippel RS \& Chen H 2002 Activation of the ras/raf-1 signal transduction pathway in carcinoid tumor cells results in morphologic transdifferentiation. Surgery 132 1035-1039 (Discussion 1039).

Sippel RS, Carpenter JE, Kunnimalaiyaan M, Lagerholm S \& Chen H 2003 Raf-1 activation suppresses neuroendocrine marker and hormone levels in human gastrointestinal carcinoid cells. American Journal of Physiology. Gastrointestinal and Liver Physiology 285 G245-G254

Tamir H, Liu KP, Hsiung SC, Adlersberg M, Nunez EA \& Gershon MD 1990 Multiple signal transduction mechanisms leading to the secretion of 5-hydroxytryptamine by MTC cells, a neurectodermally derived cell line. Journal of Neuroscience 10 3743-3753.

Tinajero JC, Fabbri A, Ciocca DR \& Dufau ML 1993 Serotonin secretion from rat Leydig cells. Endocrinology 133 3026-3029.

Tran VS, Marion-Audibert AM, Karatekin E, Huet S, Cribier S, Guillaumie K, Chapuis C, Desnos C, Darchen F \& Henry JP 2004 Serotonin secretion by human carcinoid BON cells. Annals of the New York Academy of Sciences 1014 179-188.

Van Gompel JJ \& Chen H 2004 Insulin-like growth factor 1 signaling in human gastrointestinal carcinoid tumor cells. Surgery 136 1297-1302.

Van Gompel JJ, Kunnimalaiyaan M, Holen K \& Chen H 2005 ZM336372, a Raf-1 activator, suppresses growth and neuroendocrine hormone levels in carcinoid tumor cells. Molecular Cancer Therapeutics 4 910-917.

Wallukat G 2002 The beta-adrenergic receptors. Herz 27 683-690.

Westberg G, Ahlman H, Nilsson O, Illerskog A \& Wangberg B 1997 Secretory patterns of tryptophan metabolites in midgut carcinoid tumor cells. Neurochemical Research 22 977-983.

von Wichert G, Jehle PM, Hoeflich A, Koschnick S, Dralle H, Wolf E, Wiedenmann B, Boehm BO, Adler G \& Seufferlein T 2000 Insulinlike growth factor-I is an autocrine regulator of chromogranin A secretion and growth in human neuroendocrine tumor cells. Cancer Research $604573-4581$.

Zatelli MC, Tagliati F, Taylor JE, Rossi R, Culler MD \& degli Uberti EC 2001 Somatostatin receptor subtypes 2 and 5 differentially affect proliferation in vitro of the human medullary thyroid carcinoma cell line tt. Journal of Clinical Endocrinology and Metabolism 86 2161-2169.

Zikusoka MN, Kidd M, Eick G, Latich I \& Modlin IM 2005 The molecular genetics of gastroenteropancreatic neuroendocrine tumors. Cancer 104 2292-2309.

Received 9 October 2006

Accepted 18 October 2006 